\title{
A note on the Pazos-Simonsen mechanism and Kaldor's early research on Latin American inflation
}

LEONARDO VERA*

In contrast with the inflationary finance story, inflation acceleration in Latin America has been explained as the result of the interaction of inflation dynamics and the frequency of wage adjustments. Accordingly, small inflation disturbances are connected with a shift from moderate to high inflation (or beyond to hyperinflation) though a mechanism that makes adjustment intervals in wage contracts endogenous. Rudiger Dornbusch (1986) labeled this process the "Pazos-Simonsen mechanism". In this note we summarize the basic contribution of both Felipe Pazos (1978) and Mario Henrique Simonsen (1983) and find crucial differences between their views on wage dynamics, specifically regarding the endogeneity of the time interval between wage readjustments. A remarkable affinity with Pazos's view on wage dynamics and inflation is found in an early and almost unknown essay written by Nicholas Kaldor in 1957 (inspired in his brief experience in Latin America).

Keywords: Latin America; inflation; wage dynamics; Pazos-Simonsen mechanism. JEL Classification: B31; B50; E24; E31.

\section{INTRODUCTION}

Wage dynamics, very often led by what is called a wage-price spiral, are likely to be present in an economy in which not all price and wage decisions are taken simultaneously. This means that while most wage decisions are set for discrete periods of time, nominal price changes do not take place all at the same time but rather uniformly through time. Indeed, though the interaction among price and *Universidad Central de Venezuela, e-mail: Leonardo.vera@cantv.net. Submitted: 9/August/2011;
Approved: 25/May/2012. 
wage decisions assuming continuous wage setting is possible, the mere existence of explicit and implicit wage contracts seems to indicate that the working class is essentially the social group entitled to voice its demand in an orderly fashion. Thus, the adjustment asymmetry between wage and price adjustments may be simply the unavoidable consequence of the existence of a large number of uncoordinated price setters that deals with an organized or unionized working class.

In an inflationary economy one institutional feature of a wage setting process designed to adjust the value income payments for general price-level changes is the wage contract. As inflation erodes real values and misaligns relative prices, agents are required to reset wages and renegotiate contracts by creating rules that reconstitute the claims of peak real incomes periodically. When inflation rises to two- or three-digit levels, market transactions and contracts become disrupted and it may happen that contracts start to index wages to inflation. The prevalence of formal or informal wage indexation has been pointed out as one of the reasons why inflation in some countries shows a stronger tendency to conserve momentum. What happen in this latter case is that eventually countries learn how to live with high and persistent inflation by creating various indexation mechanisms.

Interestingly enough, the recent history of the economies of Latin America have provided fertile ground for assessing the extent and impact of wage contracts and wage indexation on the process of inflation. Scholars have found that sometimes it is possible that an extended indexation system affects the dynamics of inflation in a situation in which the rate of change of the price level tends to remain constant without causing higher inflation. This tendency is related to the fact that a typical indexation scheme adjusts wages to lagged inflation.

There are situations, however, in which higher inflation in the past leads to higher wage settlements which in turn further raise inflation. An interesting explanation of this sort of inflation dynamics developed from the experiences of the Latin America inflationary episodes. This explanation shows that small inflation disturbances may be connected with a shift from moderate to high inflation (or beyond to hyperinflation) though a mechanism that makes adjustment intervals in wage contracts endogenous. Thus, as inflation accelerates, contracts shorten, and that shortening of contract is itself a factor that causes inflation to accelerate. This is actually a variant of a broad class of wage-price dynamics that was labeled by Rudiger Dornbusch (1985, p. 12) the 'Pazos-Simonsen mechanism'. In his Frank D. Graham lecture presented at Princeton University, Dornbusch (1985) argues that the principle was formulated independently by two leading Latin American economists, Felipe Pazos and Mario Henrique Simonsen, in the 1970s and in the mid 1980s respectively. The claim made an appearance once again in Dornbusch and De Pablo (1987). They argue that an essential feature of the inflation process is a melting of contract structure. Wage contracts shift to shorter intervals and immediately raise the rate of inflation and thus erode existing contracts at a more rapid rate. Then they say

"The...interesting question is what happens when the frequency of adjustment increases still further. This point has been developed parti- 
cularly by Simonsen (1983) and Pazos (1972). It is of interest here because contract deterioration is one of the important characteristics of an accelerating inflation and because exchange depreciation often plays an important role in triggering the process." (p. 87)

Dornbusch and De Pablo (1987) describe the Pazos-Simonsen mechanism as a transition from a stable to accelerating inflation process generated by workers reaction to a fall in real income below what they consider a minimum standard of living. Accordingly, since workers cannot borrow, even in perfect capital markets, then they will call for a shorter interval between wage adjustments. They discuss the characteristics of accelerating inflation in Argentina (between 1975 and 1980) and its relationship with the institutional wage setting mechanism and highlight that the process resembles the observations made by Pazos (1972) and Simonsen (1983) regarding accelerating inflationary episodes. They conclude that "it is immediately clear from the Pazos-Simonsen mechanism that the optimal incomes policy designed to avoid creating the context for an inflationary explosion is one that monitors above all the frequency of adjustments" $(1987$, p. 89$){ }^{1}$

This note attempts to contribute toward the simple understanding of the mechanism by examining its early appearance in the context of Latin American inflationary episodes of the 1950s and 1960s. The note briefly examines Pazos and Simonsen's views and brings to light an early contribution to Latin American inflation literature made by Nicholas Kaldor in a study published in Portuguese as far back as 1957. The rest of the note is organized into four sections. The next section looks at Pazos and his basic view on wage dynamics and inflation acceleration. Section third presents Simonsen's basic ideas on inflation and wage dynamics and situates them in the context of Brazilian wage indexation system. Section fourth briefly summarizes the main difference between Pazos and Simonsen and takes up the issue of the endogeneity of the wage adjustment interval. Section fifth, shows why Kaldor's 1957 essay on inflation and economic development anticipates Pazos and Simonsen's main elements of wage dynamics and inflation acceleration.

\section{PAZOS ON INFLATION AND WAGE DYNAMICS}

Felipe Pazos (1912-2001) was undoubtedly one the outstanding Latin American economists of the twentieth century. Born in Havana (Cuba), Pazos earned a doctorate from the University of Havana in 1938 and joined the Cuban foreign service. After a successful career in the foreign service, he became a member of the Cuban delegation that attended the Bretton Woods conference that created the

\footnotetext{
${ }^{1}$ Further references to the Pazos-Simonsen mechanism can be found in Coricelli and Rocha (1991) Rostowski (1994), Esteves (2003) and Rocha (2007).
} 
World Bank and International Monetary Fund in $1944 .{ }^{2}$ In 1946 , he joined the staff of the recently created International Monetary Fund (that had been established at the Bretton Woods conference). He stayed there for three years before returning to Cuba in 1950 to work on the creation of the central bank, working as his first president from 1950 until 1952 at the behest of Cuban President Carlos Prío Socarrás. After Fulgencio Batista took power in Cuba through a military coup d'état in 1952, Pazos became active in supporting the resistance against Batista. Between 1954 and 1955 Pazos was a professor of economic development in the University of Santo Tomás de Villanueva where he pioneered the teaching of modern economics in Cuba. Between 1955 and 1957, he directed the Department of Economics at Universidad de Oriente. In many ways, while living those years in Cuba, Pazos supported the revolutionary movement headed by Fidel Castro. In July 1957, Pazos and Raul Chibas (another opponent of Batista) met Castro in the mountains and together issued a manifesto intended to reassure the middle classes in Cuba about the revolutionary pledging to restore the democratic constitution of $1940 .^{3}$ When Fidel Castro seized power in 1959, Pazos was reappointed president of the Banco Nacional de Cuba, Cuba's central bank. But very soon he became disillusioned with the increasingly radical nature of the revolutionary government and resigned. ${ }^{4} \mathrm{~Pa}$ zos ended up working at the Alliance for Progress. Indeed, he was a member of the top coordinating body, the so-called "Nine Wise Men", a panel of nine economists whose main mission was to study the best manner of achieving mutual interdependent development. Later, Pazos worked for the Inter-American Development Bank, until his retirement in 1975, when he moved to Venezuela and became an economic adviser of the Venezuelan Central Bank until his death.

Pazos was not a mere civil servant with international reputation and exposure but also a theorist concerned with policy and with active management of the economy. Pazos's writings on economic development and the external vulnerability of Latin American countries were an important part of the emerging thinking among Latin American economists from the 1940s to the 1960s. In 1949 he published "Inflation and Exchange Rate Instability in Latin America", in the pages of the American Economic Review. In that article Pazos remarked the persistent tendency towards external unbalances and inflationary pressures that develop in some Latin American economies as a result of the investment boom that characterized the in-

\footnotetext{
${ }^{2}$ The Cuban delegation took a very active part in the deliberations of the conference, helping to shape the foundations of the IMF. Two of its members Luis Machado and Felipe Pazos became Executive Director at the World Bank and staff of the Fund respectively in its early years.

${ }^{3}$ Five months before that, in February 1957, Pazos and his son Xavier arranged for a correspondent from The New York Times, Herbert L. Matthews, to interview and photograph Fidel Castro and his guerrilla at their hideaway in the southern Sierra Maestra. The interviews belied the contentions by the dictatorship of Batista that Castro had been killed and propelled him and his movement into the international limelight.

${ }^{4}$ Pazos was eventually allowed to leave the country, and his Central Bank position was taken by Ernesto "Che" Guevara.
} 
dustrialization process. Later, in 1953, he publishes "Economic Development and Financial Stability", in the IMF Staff Papers, a study in which he argued that economic development and balanced growth with financial stability, although not easy, was possible. Pazos' works on tariff and economic development, optimal direct investment allocation and industrialization provide further elaborate expositions of the main problems of economic development.

Pazos was also among the first observers that pose a large number of puzzling questions regarding the process of self-perpetuating inflation in Latin America. The characterization of different types of inflation, the reasons for conservation of momentum, the situations of unceasingly rise in prices (even when real output shrinks), the factors behind inflation acceleration and deceleration and its acyclical nature, were for Pazos paramount issues looking for tentative explanations. In that sense he moved a step further from the old structuralists thinkers who concentrated very much on the activating mechanisms or inflationary impulses. Pazos's first writing on wage dynamics, entitled "Notas para un Estudio de la Espiral Inflacionaria", appeared in the well known Mexican journal El Trimestre Econom$i c o$ in 1963. But his best known publication on the subject was Chronic Inflation in Latin America, a book published in English in 1972..$^{5}$ There was some attention paid to this book amongst the relatively small group of Latin American economists interested in Latin America inflationary episodes, but little outside of that circle. It is remarkable that Sebastian Edwards, in an edited interview conducted by Jeffrey Nilsen (Study Center Gerzensee Newsletter, 2002), has stated that Pazos' book on chronic inflation is "one of the most interesting works on inflationary inertia in the world". ${ }^{6}$

In Chronic Inflation in Latin America Pazos highlights the institutional features of the inflation process in four Latin American countries (Argentina, Chile, Brazil and Uruguay) between the 1940s and the late 1960s. He compares and contrasts the riddle of the persistence of price rises in these economies with episodes of moderate inflation in developed countries and past episodes of hyperinflation in Europe. Pazos concludes, of course, that inflation episodes are not alike, but even more important than this he finds that chronic inflation exhibits singular features that do not match conventional explanations. First, he observes that in these types of inflations the view that inflation is about too much money chasing too few goods fails to give a useful idea of what in fact happens. Second, he sees the influence of inflation on the fiscal accounts and the budget deficit as a critical element. Third, Pazos argues that intermediate chronic inflation is driven in part by the pricing rules of

\footnotetext{
${ }^{5}$ The book is based on a seminal study conducted by Pazos for the Alliance for Progress and published in Spanish by Centro de Estudios Monetarios Latinoamericanos (CEMLA) in Mexico in 1969.

${ }^{6}$ Edwards points out that while he was the Chief Economists at the Latin American Desk of the World Bank, he tried to give the senior staff a better understanding of the nature of Latin American economic issues introducing the work of Pazos. He complains, however, that at the time "no one in the World Bank had ever heard of Felipe Pazos” (pp.5-6).
} 
economic agents in the goods and labor markets. Fourth, he shows that chronic inflation is a process significantly affected by the adaptation of the affected interest groups. Fifth, he sees that the external sector can play a critical role if the real exchange rates are not constant. Finally, he points out that escalation of inflation invariably involves a shortening of the adjustment periods for wage and price setting.

For Pazos (1972) contract deterioration is one the leading characteristics of an accelerating inflation. The point remarked by Pazos was simple. In an economy in which such a system of price and wage dynamics prevails, a situation of chronic but constant inflation may exist but it may not be sustainable. There are some prices that do not adjust regularly to past inflation (they show rigidity), accumulate inflationary pressures for a time and release them later. Pazos argues that the principal prices that have behaved in this manner are public utility rates, food prices (when subject to government control) and the exchange rate. Thus, even when the price and wage increases look stable, price adjustments are made, in any case, to recover the lost ground. As the ongoing inflation erodes now more rapidly the purchasing power of the constant nominal wage income, workers, in the middle of their contracts, will find that their real wages fall below what they consider a minimum standard of living (the real wage threshold) and hence they will call for a shorter interval between wage adjustments in order to recover the real wage losses imposed by inflation. This is translated into a supply shock for firms and leads to a higher inflation rate. Higher inflation in turn further shortened intervals pushing inflation up once more. For Pazos, this endogeneity of the contract length itself accelerates inflation and is the mechanism that connects small inflation disturbances with a shift from 50 to 100 percent inflation, or beyond to hyperinflation. ${ }^{7}$ Pazos (1972) describes the dynamics as follows:

"When the rate of inflation approaches the limit of tolerance, a growing number of trade unions ask for raises before their contracts become due. And management grants them. This wage increase gives an additional push to inflation and brings about a further reduction of the adjustment interval. Probably the interval is initially shortened to six months, and then, successively, to three months, one month, one week, and one day." (pp. 92-93)

The reader should notice that in this description wage revisions follow triggerpoint wage references. That is, wages are revised whenever accumulated inflation

\footnotetext{
${ }^{7}$ There is some academic literature, specifically following the works of Gray (1976 and 1978), where for any given degree of wage indexation, contract length decreases with the level of uncertainty and increases with the cost of contracting. However, most of the literature on this subject has studied the effects of wage indexation under the key assumption that indexing is instantaneous and with respect to current inflation. These neoclassical assumptions can be of little use even as a gross approximation to the issue. Indeed it has long been recognized that standard wage indexation is based on lagged rather than current inflation (see Jadresic 2002).
} 
pushes real wages to a given threshold. This is a case in which the institutional wage-setting mechanism does not necessarily rely on a fixed contract length. The process may lead to some final stages. For Pazos (1972) in the final stages of inflation, prices and exchange rates become closely tied. Since no domestic price index is available on weekly or daily basis, quotations of the exchange rate become the central pillar for calculating prices. This shift to foreign exchange based pricing leads to a big upsurge in inflation, via the once and for all elimination of lags, and ultimately all and any inertia disappeared in a process that Pazos (1972) describes as follows:

"The reduction of the interval to their shortest possible duration and the pegging of the wage adjustments — both upward and downward - to the freely fluctuating quotations of foreign currency give hyperinflation a mechanism different from that of intermediate inflation. The day to day adjustment of all contracts puts an end to all connections between the value of transactions in successive periods..." (p. 93)

But it is important point out that without monetary accommodation this process could not go far. Thus in the transition from chronic and high inflation to hyperinflation the frequency of adjustments becomes endogenous as well as the money growth.

\section{SIMONSEN'S BASIC IDEAS ON WAGE DYNAMICS}

Mario Henrique Simonsen (1935-1997) was one the most respected and influential Brazilian economists of his generation. Together with the late economist Celso Furtado, Simonsen was widely acknowledged in Brazil to be one of the leading intellectual figures in the field of economics. He was trained as a civil engineer at the University of Brasil in the late 1950s and as an economist later in the early 1960s. Simonsen became a recognized economist due to his talent and inspiring academic production but also because of his participation in public affairs. He was one those rare scholars who was able successfully to bridge the gap between the world of learning and practical affairs. For over 30 years he participated in public policy discussions and decisions in Brazil, either as a government official or as one of its chief economic advisers. ${ }^{8}$ Simonsen's career as a public servant started during the military government of Castello Branco (in 1964) when he collaborated with the Minister of Planning, the economist Roberto Campos, in the design of an stabilization program known as Programa de Ação Econômica do Governo (PAEG). ${ }^{9}$

\footnotetext{
${ }^{8}$ Simonsen also served on the boards of several major corporations and as a partner of Brazilian businessman Julio Bozano, of Banco Bozano Simonsen.

${ }^{9}$ Fishlow (2005) points out that indexation was the principal novelty embedded in the PAEG, and for which Mario Henrique Simonsen was responsible.
} 
Simonsen also served as Brazil's Finance Minister in the tumultuous 1970s during the military government of Ernesto Geisel and in 1979, during the government of Joao Baptista Figueiredo, he became Planning Minister, but left six months later after losing a struggle with Antonio Delfim Netto, his successor as Finance Minister. Because of his involvement with the military governments (even when he did not approve of particular government policies) he was often criticized by the Brazilian left.

Simonsen's academic career was concentrated in Rio de Janeiro. In 1965 he became the first Director of the School of Graduate Studies in Economics (EPGE) at Getulio Vargas Foundation where he inspired generations of Brazilian students whom he loved to engage with on the major economic and social issues of the day. In 1974 he left Rio for Brasilia but he resumed his activities as a Director of EPGE in 1979 and retired in 1993.

A prolific writer, Simonsen published not only many scholarly articles but also several textbooks (on Macroeconomics, Microeconomics and Economic Dynamics). Simonsen's peculiar interest for mathematics was well known. He was self-trained in the subject and as an applied mathematical economist his distinction lays in providing a bridge between different schools of though in modern economics. For that reason and for most of his career he was considered an eclectic thinker. He made outstanding contributions to economic theory and policy that cover a wide variety of subjects; but unfortunately most of his published articles and scholarly works have been overlooked outside Brazil. ${ }^{10}$ Between 1963 and 1965 Simonsen wrote several seminal studies on Brazil's economic problems and the inflationary experience of the country (see Ramalho 2003). He understood very well the critical role that wage contracts play in the evolution of inflation in the late $60 \mathrm{~s}$ and later he arrived at a view of inflation known as the "Model of Inflationary Feedback" which introduced the notions of self-perpetuating or inertial inflation (or inflation institutionalized through indexation) that became popular among Latin American scholars in Brazil and other Latin American countries in the 80s (see Simonsen 1970). ${ }^{11}$ Among eminent Brazilian economists, Simonsen was the first to argue that indexation hampers the effectiveness of the fight against inflation. From the early 70s on, he preached this thesis in his classes, his books, articles and speeches as a finance minister. It was in the 1980s that Bresser-Pereira and Nakano (1984), among other Brazilian economists, seized on Simonsen's idea and used it to underlie the differences between the factors that accelerate an inflationary process from those that perpetuate it.

\footnotetext{
${ }^{10}$ Most of his pre-1980s writings were in Portuguese — hardly a lingua franca for economists - and for that reason did not reach a wide audience outside Brazil. Some of Simonsen's contributions have been recently summarized by Barbosa (1997), Boianovsky (2002) and Cysne (2003).

${ }^{11}$ An interesting parallel with the work of Felipe Pazos who also came to the study of inertial inflation in the mid and late 1960s and when writing his Chronic Inflation in Latin America in the early 1970s. Indeed, both Bresser-Pereira (1990 and 1996) and Vernengo (2005) have argued that precursors or pioneers of the idea of inertial inflation were Simonsen (1970) and Pazos (1972).
} 
In the early 1980s Simonsen started a strong friendship and academic collaboration with Rudiger Dornbusch (then Ford International Professor of Economics at MIT). In 1983 they published the book Inflation, Debt, and indexation, a collection of twelve essays that ranged from highly theoretical discussions to practical experiences on indexation in Brazil and Europe. Later in 1986 both, Dornbusch and Simonsen, wrote an extensive and very influential study for the group of thirty entitled "Inflation stabilization with Incomes Policy Support," where they spell out some of the special features of stabilization programs in Argentina, Brazil and Israel and the resulting intellectual case for heterodox programs.

No doubt, Simonsen's scholarly work shows that he had a vision of an economy facing chronic and persistent inflation. Simonsen firmly thought that the combination of a fixed wage contract length, wage contracts with lagged indexation provisions and passive monetary policy was likely to produce an inflation process with a large degree of persistence. The conditions required for this stability of the wage-price spiral are embodied in a simple diagram of wage dynamics attributed to Simonsen by several Brazilian scholars. According to Barbosa (1997), Simonsen outlined this so-called "Simonsen Curve" (and the typical oscillatory behavior of real wages) in his book A Experiencia Inflacionaria Brasileira, in 1964. We want to make here the important point that both Barbosa (1997) and Campos (1998), in their revision of Simonsen's work, consider the Simonsen Curve as one of his major contributions.

A relevant passage from A Experiencia... (the chapter that deals with the sociopolitical roots of inflation) may help to illustrate Simonsen's point regarding wage dynamics:

"Besides the chronic increase in prices, an important phenomenon tends to unfold: the oscillation of real income among different individuals... The case of wage earners (globally the most important) is typical: as nominal wages readjust discontinuously and prices increase continuously, workers' purchasing power shows an oscillatory movement. But after the wage readjustment, real wages reach a peak and since workers' nominal income remains fixed, its purchasing power progressively declines until a new wage adjustment takes place. The wage rate jumps to its peak and the process goes on." (p. 17)

The importance that both Barbosa (1997) and Campos (1998) attach to the Simonsen curve proves fruitful and full of interest since it supplies the key elements to understand different families of wage dynamics. ${ }^{12}$ The curve is basically a simulation of the behavior of real wages over time; an evolution that is governed by three factors: a peak or target real wage, the rate of inflation, and an adjustment

\footnotetext{
${ }^{12}$ After this initial appearance of the Simonsen curve, it took a few years for diagrams of wage dynamics to make its way into standard Brazilian explanations of the behavior of inflation. See for instance Lara Resende and Lopes (1981), Lopes (1985a) and Lopes (1985b).
} 
period for wage setting. In a situation of chronic but constant inflation, institutional wage-setting mechanism may rely on a fixed contract length, with wage adjustment occurring at specific intervals. ${ }^{13}$ This is shown in Figure 1 where it is assumed that real wages are adjusted at the end of a given period, during which prices have been rising. Therefore, the given loss of real income caused by rising prices will only be recovered after some time has passed. In the figure wage dynamics also displays full sincronization of wage adjustments (staggering has been avoided), and price inflation is constant. Notice that the rate of price inflation is given by the clockwise rotation about $w^{\mathrm{T}}$ (the wage peak) that carries one line into the other. In other words, the negative angle it represents price inflation. If the inflation rate is constant, wage earners will not be able to maintain their peak income, but will maintain a constant average real wage, $\mathrm{w}^{\text {ave }}$.

Figure 1: The Simonsen Curve

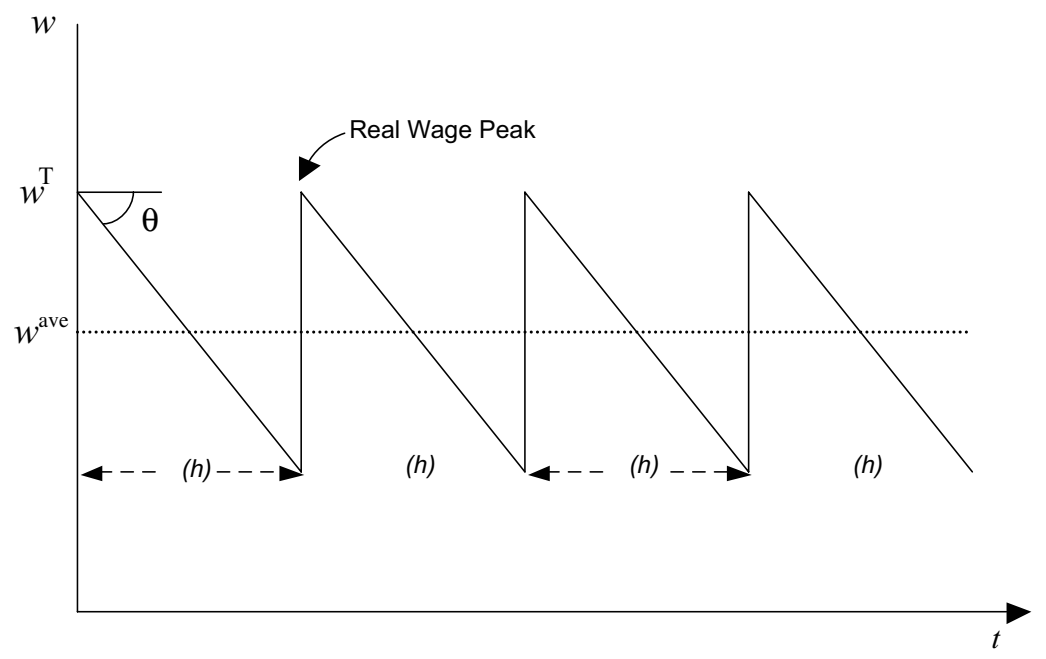

Wage indexation laws were introduced in Brazil in 1965 and since then wage adjustment for past inflation occurred in fixed intervals as in the original Simonsen curve. However, in November 1979, just at the time of the Second Oil Shock, a change in the existent indexing law reduced the adjustment interval for wages from one year to six months, with no downward revision of the real wage base. As it turned out, there was a leap in inflation (the previous annual rate quickly doubled) and inflation in Brazil remained rapid, in spite of reductions in aggregate demand in the early and mid-1980s. It was in attempting to explain the acceleration of inflation in Brazil that occurred after the change in wage policy in 1979 that Simonsen

\footnotetext{
${ }^{13}$ Alternatively, wage revisions could approximately fix the real wage by establishing trigger-point indexation, a type of indexation in which wages are revised whenever accumulated inflation is larger than a given threshold. This is a case in which the institutional wage-setting mechanism does not rely on a fixed contract length.
} 
hit upon the idea that the shortening of the wage readjustment interval had something to do with the acceleration of inflation. ${ }^{14}$ Simonsen put forward a straightforward explanation in Indexation: Current Theory and the Brazilian Experience, an essay written in 1981 and presented the same year at a conference sponsored by the Getulio Vargas Foundation in Rio de Janeiro. The conference papers (along with this Simonsen's essay) were published two years later in Dornbusch and Simonsen (1983).

The explanation given by Simonsen (1983) is based on the assumption of lagged wage indexation. For Simonsen is not perfect indexation but lagged wage indexation "the usual type of wage contract found in real life" (p. 102). He points out that the reason is partly to be found in the inevitable information lag. He argues that "in a perfectly indexed labor contract nominal wages should be made proportional to the consumer price index of the payday. And, as long as a minimum time period (for example, one month) is required to compute the price indexes and transfer their results to the payrolls, indexation can never be perfect" (p. 102). Moreover, wage revisions due to indexation in practice are not done in every possible period. This means that indexation is not, in general, instantaneous. ${ }^{15}$

Simonsen uses a very compact model that includes a wage equation with an imperfectly indexed part of the wage increase and a rational expectation component, and a price equation with a Phillips relation. He demonstrates that indexation in its lagged form is an inflationary perpetuating mechanism and that the unemployment costs to fight inflation, under these circumstances, is considerable high.

Now, Simonsen argues that since perfect indexation (no lags in wage readjustments) has the virtue that makes inflation easier to fight, one may be tempted to recommend a drastic shortening of the wage-adjustment interval. Simonsen claims that with full lagged indexation this logic is fraud and that if wage adjustments are shortened, say, from one year to three months, annual inflation becomes the quarterly rate of inflation. He firmly states:

"According to our model in section 5.3, the reduction of the wage-adjustment interval with no downward revision of the real wage basis should lead either to massive unemployment or to a sudden leap in the inflation rate" (p. 122).

In Simonsen's model the reduction of the time interval between readjustments leads to costs pressures and a reduction in firms realizes mark-ups. If firms allow this reduction in their mark-ups, then the shortening of the readjustment interval implies a higher average real wage (over the shorter adjustment interval) and high-

\footnotetext{
${ }^{14}$ Early on Lopes and Lara Resende (1979) had used the Simonsen curve

${ }^{15}$ As we point out before most of the neo-classical literature on the subject of indexation studies the effects of wage indexation under the key assumption that indexing is with respect to current inflation. This assumption implies that wage indexation helps to stabilize the real wage, which in standard models has strong implications on the behavior of the economy.
} 
er unemployment. It is likely, however, that firms try to protect their mark-ups bringing the average real wage down to their previous level. In that case, the result is an increase in the rate of inflation (but not its acceleration).

Figure 2: Transition a Shorter Contract mlenght

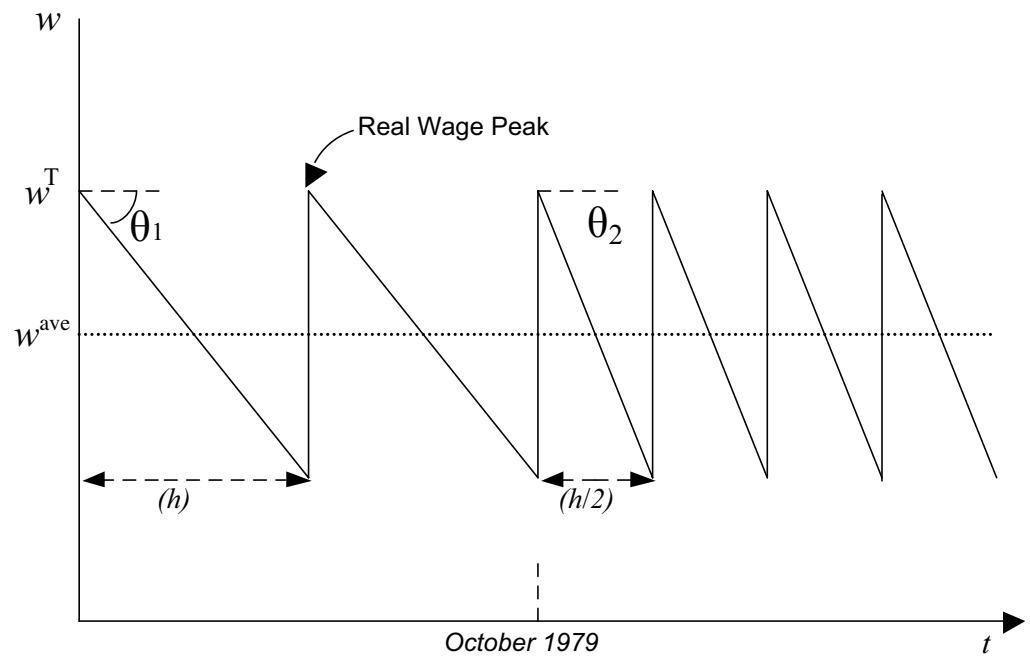

Before October 1979 the nominal wage is readjusted annually and price inflation (given by the negative angle $q_{1}$ ) is constant. Over time this always brings the real wage to the average level $\mathrm{w}^{\text {ave }}$. In October 1979, the interval is reduced to six months. The shortening of the re-contracting interval would imply a higher average for a given inflation rate. But firms will not allow a reduction in their effective mark up and price inflation increases (the negative angle changes to $q_{2}$ ) so as to bring the real wage to the previous average level.

The trade-off between the shortening of the wage readjustment and the rate of inflation can be better understood and formalized following somewhat the presentation made by Brazilian economist Persio Arida (1982).

Consider the variables $P(0)$ and $W(0)$ as a representation of the initial price level of the economy and the nominal wage earned by workers respectively and at time $t=0$. The nominal wage $W(0)$ is the result of a wage bargaining problem between firms and organized workers (or it is adjusted through an automatic indexation mechanism). Let us assume that at time $t=0$, workers achieve their target real wage $w^{\mathrm{T}}$ which may be given by the following expression in log terms

$$
w^{T}-\ln \left(\frac{W(0)}{P(0)}\right)
$$

Now let $h$ stands for the length of the interval between wage readjustments. Since nominal wages are not readjusted continuously, then for interval $0 £ t £ h$ the level of nominal wages $W(t)=W(0)$. However prices are marked-up continu- 
ously so that their variation can be represented by a uniform or geometric rate of growth $p$. This implies that

$$
P(t)=P(0) e^{\pi t} ; 0 \leq t \leq h
$$

Over a time period $h$ the log of the effective real wage determined by the price policy of the firms is

$$
\ln \left(\frac{W(0)}{P(t)}\right)=w^{T}-\pi t
$$

This means that the rate of inflation and the effective real wage earned by workers are inversely related. If firms set the inflation rate so as to make the average real wage in the period equal to $w^{\text {ave }}$ then

$$
w^{a v e}=\frac{1}{h} \int_{0}^{h} \ln [W(0) / P(t)] d t=w^{T}-\frac{\pi}{2} h
$$

Expression (4) which derives from the behavior of firms can be rewritten as

$$
w^{T}-w^{a v e}=\frac{\pi}{2} h
$$

Note that the left hand side of (4a) shows the intensity of the distributive conflict between organized workers and firms. If the peak or target real wage is given exogenously, and firms set prices so as to push real wages to a pre-determined level, then expression (4a) tell us that inflation will be higher the shorter the contract length. In particular, when the period $b$ is reduced by half, the inflation rate doubles. ${ }^{16}$

Now, in analyzing Simonsen's relation between the time interval and the rate of inflation we found it important to distinguish between situations in which the wage readjustment interval is legally set by government authorities, on the one hand, and situations in which spontaneous bargaining reactions make the wage readjustment interval endogenous, on the other. Pazos's wage dynamics are very much of the second type, while Simonsen's analysis, unfortunately, takes the wage readjustment interval as an exogenous variable. In fact, Pazos's main point regarding wage contracts is that in the absence of transaction costs, an inflationary situation may be faced by economic agents by much more frequent wage adjustments. In contrast, in an economy in which indexation is recognized as a useful contractual arrangement, as the one analyzed by Simonsen (1983), indexation itself may be a form of economizing in the face of this need.

Judging by the analysis presented by Simonsen (1983), there is some confusion

\footnotetext{
${ }^{16}$ One can easily show from (4a) that the average real wage approaches the target as $h$ approaches to zero, that is, the average real wage becomes the target when there is instantaneous indexing.
} 
over his contribution regarding wage dynamics. Simonsen does not argue that workers, in the middle of their contracts, will call for a shorter interval between wage adjustments once they find that their real wages fall below what they consider a minimum standard of living. He just underlines the trade-off that may exist between the shortening of the wage readjustment interval and the rate of inflation. To what extent this allows a full description of the mechanisms leading to accelerating inflation? It is something that we've left to the reader.

\section{EXPLOSIVE INFLATION DYNAMICS}

Simonsen's effort to understand persistent inflation, though important, fell short of a comprehensive understanding of the relationship between wage dynamics and inflation acceleration because his analysis neglected indeed two as aspects that occupied a central place in Pazos's study of inflation acceleration. First, Pazos (1972) finds a significant lack of symmetry in price adjustment, indicating that many prices are not changed in a given period. This implies that some prices in the economy show rapid price adjustments while in some sectors or industries one can find price changes to be remarkably infrequent. As we remark above, for Pazos public utilities rates, basic good prices that are subject to government control, and the exchange rate are typical examples of the latter case. These prices accumulate inflationary pressures for some time and release them later causing inflationary disturbances. Secondly, Pazos's description of the inflation process makes it clear that the dramatic escalation of inflation, seemingly out of proportion to the disturbances, arises from the endogeneity of the adjustment interval.

Drawing on Pazos's interpretation of inflation processes, positive price disturbances or supply shocks may increase the inflation plateau, which in turn erodes real wages more rapidly over the adjustment interval. Under these circumstances the wage adjustment interval is unlikely to remain fixed. Consequently, the reduction of the contract length materializes as a higher inflation level over the period. To this one must add the feedback effects between inflation and the adjustment interval.

This two-way relation between inflation and the wage readjustment interval can be easily incorporated in the formalization shown above, though it renders the dynamics a little bit more complex. This is because it will introduce feedback effects. Let us first take the expression (4a) that shows the trade-off between the wage readjustment interval and the rate of inflation and rearrange to have

$$
\pi=\frac{2 \Omega}{h}
$$

where $\Omega=w^{T}-w^{\text {ave }}$ captures a predetermined intensity of the distributive conflict. The key innovation now will make the readjustment interval a negative function of the inflation rate, that is 


$$
h=\sigma+\frac{1}{\pi}
$$

In (6) the readjustment interval is therefore endogenous since it is negatively related to changes in $p$ while any exogenous variation in the readjustment interval is still captured by changes in the parameter $\sigma$. The dynamics of the model can be analyzed graphically as it is done in Figure 3. The figure is plotted in the wage readjustment interval-inflation space. Both schedules representing expressions (5) and (6) are negatively sloped reflecting the fact that increases in the rate of inflation reduce the wage readjustment interval and reductions in the wage readjustment interval increase the rate of inflation. Looking at Figure 3, if we consider, for instance, an arbitrary initial contract length associated with an inflation rate through equation (5), then the rate of inflation has its feedback on $b$ though relation (6). It is clear that the two-way relation between inflation and the wage adjustment interval is unstable and inflation accelerates indefinitely.

Figure 3: Unstable inflation dynamics when the frequency of wage adjustments is endogenous

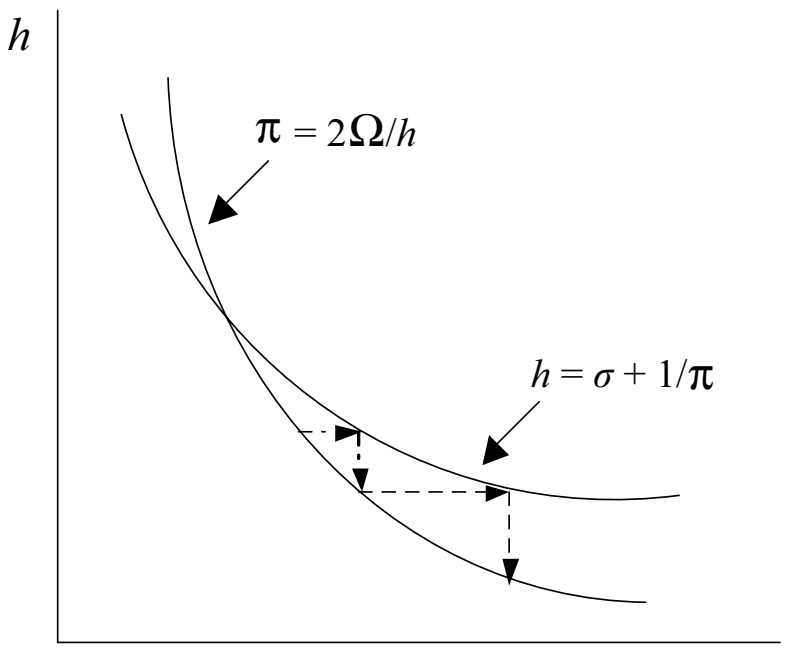

$\pi$

But such a highly unstable process cannot be a fair representation of any inflationary episode because it means that any chance increase in prices that accumulate inflationary pressures would destabilize the system through indefinite inflationary expansions. Pazos (1972) was absolutely aware of this and for that reason he stated that the long durations of the inflations in Latin America show that the trend towards inflation acceleration does not operate in a continuous form, and that, when it operates, it can not escape from other offsetting forces. 


\section{KALDOR'S EARLY FORMULATION}

As Targetti and Thirlwall (1989) have suggested, Kaldor had a long-standing interest in the topic of inflation. His second public lecture delivered at the London School of Economics and Political Science (LSE) on February 6 and 13, 1959 (Kaldor 1959) as well as his Presidential address to the Royal Economic Society on July, 1976 (Kaldor 1976), are widely regarded as his best known works on the subject. However, Kaldor's concern and academic interest on inflation can be traced back to his years as a policy adviser and invited lecturer in Latin America. ${ }^{17}$ Indeed, between 1956 and 1957 Kaldor wrote and published two essays in which we can find insightful elements of a theory of Latin American inflation. The first of these studies was written while Kaldor worked for the United Nations' Economic Commission for Latin America (ECLA) in Chile. ${ }^{18}$ It was a study analyzing Chile's accumulation and inflation problems. This essay was written during his last two months in Chile (August and September 1956), but it was only the second part of the paper (the one dealing with inflation and the role of wage goods) that was immediately published a year later (see Kaldor, 1957a). ${ }^{19}$ Kaldor's basic idea in this first study entitled La Inflación Chilena y la Estructura de la Producción, goes along similar lines pointed out previously by Kalecki (1954). Put briefly, inflation develops as an attempt by workers and capitalists to maintain living standards when in an ongoing process of economic development there is a lagging agricultural sector. Then, inflation was seen as the result of initial upward pressures caused by capacity or output constraints (in that sense it was demand-induced as far as agricultural products were concerned); but later on, in an attempt to avoid real income losses, workers and capitalists would induce cost and price increases in the non-agricultural sectors with self-reinforcing effects.

\footnotetext{
${ }^{17}$ A few months before his death, in a personal recollection, Kaldor pointed out; however, that its initial curiosity on inflation was aroused by a first hand experience of inflation in Germany during the early 1920s (see Kaldor 1986).

${ }^{18}$ Kaldor first visit to Latin America occurred in 1956 . He was invited by Raul Prebisch to work for ECLA at its headquarters in Chile. Kaldor arrived in Santiago at the end of June after brief stops in Mexico City and Lima (Palma and Marcel, 1989). He stayed in Santiago for three months. His main task was to advise ECLAC in their first studies on fiscal policies but he also gave more than twenty lectures on various topics.

${ }^{19}$ Palma and Marcel (1989) made a comprehensive and outstanding analysis of Kaldor (1957a) and explain the reasons why this study on the Chilean economy found mounting difficulties to be published immediately as a United Nations document. Apparently, his policy recommendation on taxation (contained in the first part) raised increasing objections during the Chilean presidential election campaign, in which the conservative candidate Jorge Alessandri was finally elected President. Since ECLA did not object the part related to inflation, Kaldor approved his publication in the Chilean journal Panorama Economico in 1957. Finally, under the support of the ECLAC's Executive Secretary the entire study was then published in the Mexican journal El Trimestre Economico, in April 1959.
} 
The second study was the final result of some preparatory notes presented in Rio de Janeiro in October of 1956. It was by the end of the year 1956 and after his three months stay in Chile, that Kaldor travelled to Brazil, where he attended a meeting of the International Economic Association and gave several lectures at the Getulio Vargas Foundation in Rio. The lectures contained the preparatory notes for five essays that were published a year later (in 1957) in the well-known Brazilian academic journal Revista Brasileira de Economia. ${ }^{20}$ The entire set of lectures (with the five essays) was published in Portuguese but later translated into Spanish and published in 1962 in Revista de Economia Politica (an academic journal edited in Spain and sponsored by the Center of Political and Constitutional Studies). No record of these lectures can be found in English.

Kaldor's second study entitled Inflação e Desenvolvimento Econômico (Inflation and Economic Developmen) was a bit different from the first. Kaldor's analysis did not concentrate in any specific economy. Moreover, Kaldor's emphasis shifted, fundamentally, away from the analysis of the sectoral imbalances towards a theory of surplus mobilization for development purposes. Kaldor's inflation theory hinges now on the observation that a higher rate of progress requires additional savings and that savings can only be generated out of a surplus of production over minimum essential needs. Inflation starts as an investment boom and hence as a profit inflation in its early stages. Kaldor assumes that output is supplyconstrained and will not respond to changes in demand, therefore, a forced redistribution of income allows profits to rise more than wages, capital accumulation is accelerated and luxury consumption increases. But he recognizes that without a continued rise in money wages inflation could not go on as a process in time. Kaldor then argues that it is in times of high business activity that workers bargaining power increases, strike action is both costly to the employers and the rise in profits governs the employers' ability to grant wage increases. Kaldor's basic point of view is then that profit inflation in its early stages is likely to turn into wage inflation. ${ }^{21}$

Hence, Kaldor devotes in this essay much more attention to wage dynamics. Kaldor observes that nominal wages begin to change periodically based on the change in the living cost. Kaldor argues that "once wages begin to be periodically adjusted to the change in the living costs, a number of things is likely to happen" (p. 67).

\footnotetext{
${ }^{20}$ Kaldor's lectures provide a very complete account of the main problems facing developing countries at the time. The topics covered in the essays and published in the same order were: The Characteristics of Economic Development, Balanced and Unbalanced Growth, The Problem of Accelerated Growth, Inflation and Economic Development and Taxation and Economic Development.

${ }^{21}$ There is no question that Kaldor's examination of the problem of inflation in this essay was a formative influence on the theory of inflation that he presented in his public lecture delivered at the LSE in 1959.
} 
For Kaldor the frequency of wage adjustments was critical. But it is convenient to understand first Kaldor's reasoning regarding the way wage and price changes occur in a typical developing country. He clearly understood that the mechanisms behind wage and price adjustments were different. Thus, he argues that

"while the adjustment of prices to changes in wages is gradual, the adjustment of wages to changes in prices tend to occur periodically considering, at one stroke, the accumulated change in the cost of living relative to some previous base date" (p.67).

Kaldor then focus on what he views as the more direct symptom that appears associated with the mechanism of wage dynamics: inflation acceleration. He explains,

"the symptoms of an acceleration in the rate of increase of prices, caused by the wage/price spiral, force the government and the Central Bank to take counter measures in the form of an increasingly restrictivecredit policy" (p. 67).

Next, Kaldor sees real wages fluctuating around an average set by two extremes. There will be no mayor problem if we call these extremes the "peak real wage" and the "trigger-point" or "threshold". Indeed he writes

"Real wages thus fluctuates around an average set by the extremes of the level of wages immediately prior to and immediately after a particular adjustment." (p. 67)

But crucially important is the fact Kaldor estimates that between settlement dates as inflation goes on, nominal wages are reset once the actual real wage reaches a fix or predetermined threshold and this may happen even before the settlement date. The way Kaldor illustrates this process is by using a wage dynamics diagram. Indeed Kaldor made a pioneering contribution on the issue of wage dynamics by introducing for the first time in a journal article this diagram. The diagram, reproduced here in Figure $\mathrm{N}^{\circ} 4$, underlines a behavioral assumption that makes adjustment intervals in wage adjustment or contracts endogenous and inflation accelerating - as in the Pazos mechanism. Quoting Kaldor

"The characteristic of the wage/price spiral is that the zig-zag becomes increasingly compressed. This means, of course, a continued acceleration in the rate of increase in the general price level.” (p. 67) 


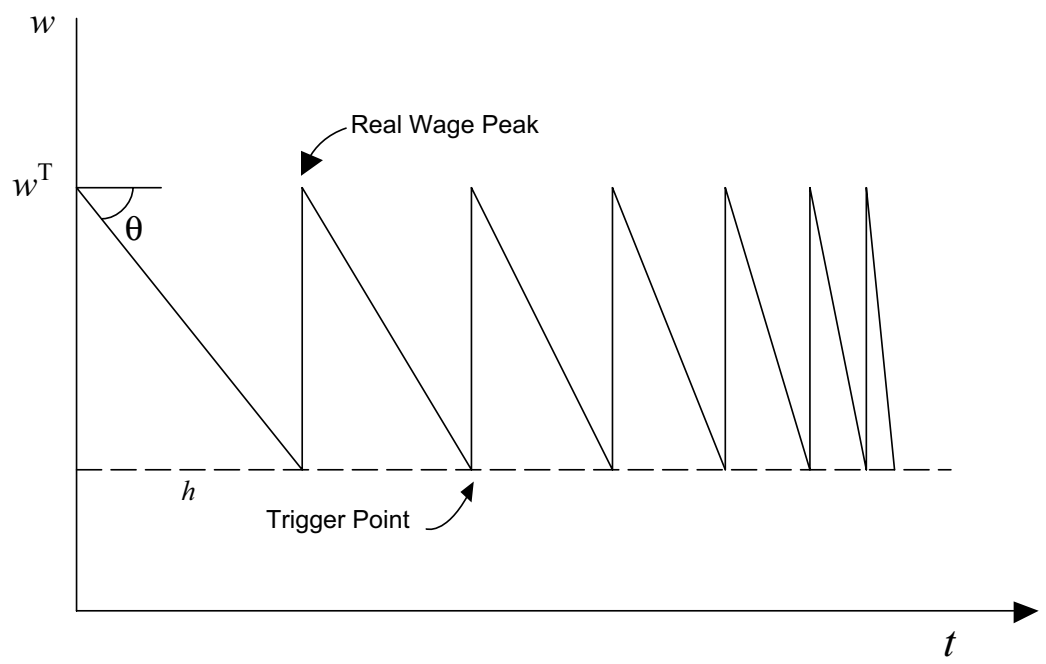

Consequently, Kaldor deserves not only the credit for having presented this pedagogic diagram for the first time, but also he really discovered, even before Pazos (1972) and Simonsen (1983), the analytical importance of the endogenous variations of contract length to explain a continued acceleration of inflation.

Moreover, as Kaldor understood matters in his second study, the course of inflation is likely to exhibit two distinct phases: one during which profits rise more than wages, capital accumulation is accelerated and employment grows, and one in which the Central Bank reaction function reverses all these trends. Kaldor tries to explain the second phase as follows

"the symptoms of an acceleration in the rate of increase of prices, caused by the wage/price spiral, force the government and the Central Bank to take countermeasures in the form of an increasingly restrictive credit policy." (p. 67)

For Kaldor this in turn causes a fall in investment in real terms and may even cause considerable unemployment, reversing inflation acceleration without bringing the wage/price spiral to an end. Thus, Kaldor seems to undercover the reasons why an acceleration of inflation of the type later described by Pazos (1972) does not necessarily lead towards hyperinflation.

\section{CONCLUSIONS}

George Feiwel (1975) has correctly pointed out that it is a truism that no scientist or researcher works in a vacuum and that his discovery is not totally new. Though both Pazos and Simonsen may have arrived independently at basically 
similar conclusions regarding the relationship that prevails between inflation and the wage readjustment interval, Simonsen's analysis did not offer any explanation as to how an economy passes from stable to accelerating inflation. Pazos's seminal contribution was to underscore the importance of the contract length in inflation acceleration. He made it very clear that the key ingredient to explain inflation acceleration is the endogeneity of the adjustment interval. We have shown that the affinity of Pazos's view on wage dynamics with the early Kaldorian analysis is remarkable.

In contrast with Pazos and Simonsen who showed a long devotion to the analysis of inflation in Latin America, Kaldor's interest and written legacy on inflation in developing countries was more occasional and compact. However, Kaldor absolutely unknown essay on inflation in developing countries (inspired in his brief experience in Latin America) is a good example of how he displayed a genius for perceiving the substantive components of a problem and distilling its essential theoretical content.

\section{REFERENCES}

Arida, P. (1982) "Reajuste salarial e inflação", Pesquisa e Planejamiento Economico, 12 2: 311-342.

Barbosa, F. H. (1997) “Contribuição academica de Mario Henrique Simonsen”, Revista de Econometria, 17 1: 115-130.

Bresser-Pereira, L.C. and Y. Nakano (1984) "Fatores aceleradores, mantenedores e sancionadores da inflação", Revista de Economia Política, 4 (1): 5-21.

Bresser-Pereira, L.C. (1990) “Da inflação à hiperinflação: Uma abordagem estruturalista”, in Rego, J.M., (Ed.), Inflação e Hiperinflação: Interpretações e Retórica. São Paulo, Editora Bienal: 7-28.

Bresser-Pereira, L.C. (1996) “A inflação decifrada”, Revista de Economia Politica, 16 (4): 20-35.

Boianovsky, M. (2002) "Simonsen and the early history of the Cash-in-advanced Approach", European Journal of History of Economic Thought, 9 (1): 57-71.

Campos, R. (1998) “Mário Henrique Simonsen, um matemático humanista”, Revista Brasileira de Economia, 52 (edição especial).

Coricelli, F. and R. Rocha (1991) "Stabilizations programs in eastern Europe: A comparative analysis of the Polish and Yugoslav programs of 1990", Working Paper Number 732, Countries Economic Department, The World Bank, Washigton D.C.

Cysne, R.P. (2001) “Mario Henrique Simonsen”, Estudos Avançados, 15 (41): 139-154.

Dornbusch, R. (1985) “Inflation, exchange rates and Stabilization”, Frank D. Graham Lecture presented at Princeton University, Working Paper No. 1739, National Bureau of Economic Research, Cambridge, MA.

Dornbusch, R. and J.C. De Pablo (1987) "Debt and macroeconomic Instability in Argentina”, in Sachs, J. (ed.) Developing Country Debt and Economic Performance, Book One, National Bureau of Economic Research.

Esteves, J. (2003) "El horizonte abierto de la obra de Felipe Pazos", Association for the Study of the Cuban Economy, Especial Studies $n^{\circ} 1$.

Feiwel, G. (1975) “Kalecki and Keynes”, De Economist, 123 (2): 164-197.

Fishlow, A. (2005) "Thirty years of combating inflation in Brazil: from the PAEG (1964) to the Plano Real” (1994), Working Paper Number CBS-68-05, Centre for Brazilian Studies, University of Oxford.

Gray, J. (1976) "Wage indexation: A macroeconomic approach", Journal of Monetary Economics, 2 (2): 221-235. 
Gray, J. (1978) “On indexation and contract length", The Journal of Political Economy, 86 (1): 1-18. Jadresic, E. (2002) "Wage indexation and output stability revisited", Journal of Money, Credit, and Banking, 34 (1): 178-196.

Kaldor, N. (1957a) "La inflación chilena y la estructura de la producción”, Panorama Económico, 180 , Nov.

Kaldor, N. (1957b) "Inflação e desenvolvimento econômico", Revista Brasileira de Economia, 11 (1): 55-82.

Kaldor (1959) "Economic growth and the problem of inflation", Economica, 26 (104): 287-298.

Kaldor, N. (1961) "Características del desarrollo económico", Revista de Economía Política, 28.

Kaldor, N. (1976) "Inflation and recession in the world economy", The Economic Journal, 86 (344): 703-714.

Kalecki, M. (1954) "El problema del financiamiento del desarrollo económico", El Trimestre Economico, 21 (4): 381-401.

Lara Resede, A. and F. Lopes (1981) "Sobre as causas da recente aceleração inflacionária", Pesquisa e Planejamiento Econômico, 11 (2): 311-342.

Lopes, F. (1985a) "Sistemas alternativos de indexação salarial: uma análise teorica”, Pesquisa e Planejamiento Economico, 15 (1): 107-138.

Lopes, F (1985b) “Inflação inercial, hiperinflação e desinflação: Notas e conjeturas”, Revista de Economia Política, 5 (2): 135-151.

Palma, G. and M. Marcel (1989) “Kaldor on the 'discreet charm' of the Chilean bourgeoisie”, Cambridge Journal of Economics, 13 (1): 245-272.

Pazos, F. (1949) "Inflation and exchange instability in Latin America", The American Economic Review, 39 (3), Papers and Proceedings: 396-405

Pazos, F. (1953) "Economic development and financial stability", IMF Staff Papers, 3, (2): 228-253.

Pazos, F. (1963) "Notas para un estudio de la espiral inflacionaria”, El Trimestre Económico, 30.

Pazos, F. (1969) Medidas para detener la inflación crónica en América Latina, México: Edicones CEMLA.

Pazos, F. (1972) Chronic Inflation in Latin America, New York: Praeger Publishers.

Ramalho, V. (2003) "Simonsen: Pioneiro da visão inercial de inflação", Revista Brasileira de Economia, 57 (1): 223-238.

Rocha, R. (2007) "Inflation and stabilization in Yugoslavia", Contemporary Economic Policy, 10 (4): $21-38$.

Rostowski, J. (1994) “Labour markets and wages policies during economic transition”, CASE Research Foundation, Working Paper 83-86296-10-0, Warsaw.

Simonsen, M. H. (1964) A Experiência Inflacionária no Brasil, Rio de Janeiro: IPES Editora.

Simonsen, M. H. (1970) Inflação: Gradualismo $x$ Tratamento de Choque. Apec Editora, Rio de Janeiro.

Simonsen, M. H. (1983) "Indexation: current theory and the Brazilian experience", in Dornbusch, R. and M. Simonsen (eds), Inflation, Debt, and Indexation, The MIT Press.

Study Center Gerzensee (2002) Newsletter, Edited Interview to Sebastin Edwards conducted by Jeffrey Nilsen, Switzerland.

Targetti, F. (1992) Nicholas Kaldor. The Economics and Politics of Capitalism as a Dynamic System, Oxford, Oxford University Press.

Vernengo, M. (2005) "Money and inflation: A taxonomy", in Arestis, P. and M. Sawyer (eds) A Handbook of Alternative Monetary Economics, Edward Elgar. 